Building Services Engineering

Research and Technology

\title{
Installation of roof-top solar PV modules and their impact on building cooling load
}

\begin{tabular}{|c|c|}
\hline Journal: & Building Services Engineering Research and Technology \\
\hline Manuscript ID: & BSE-C-13-064 \\
\hline Manuscript Type: & Original Manuscript \\
\hline Date Submitted by the Author: & 12-Sep-2013 \\
\hline Complete List of Authors: & $\begin{array}{l}\text { Kotak, Yash; Edinburgh Napier University, } \\
\text { Jadraque Gago, Eulalia; University of Granada, } \\
\text { Mohanty, Parimita; The Energy and Resources Institute (TERI), } \\
\text { Muneer, Tariq; Edinburgh Napier University, }\end{array}$ \\
\hline Keywords: & Climate change, Solar PV modules, Building cooling load, $\mathrm{CO} 2$ emissions \\
\hline Abstract: & $\begin{array}{l}\text { It has been shown by many researchers that over a long term there has } \\
\text { been a slow but steady rise of ambient temperature within the Indian sub- } \\
\text { continent. Due to an increased economic prosperity there has been an } \\
\text { accompanied increase in the urban heat island effect. Furthermore, } \\
\text { urbanisation of large cities in India has also led to higher population } \\
\text { densities. The above factors had the combined effect of a significant } \\
\text { increase of cooling load of buildings. } \\
\text { The high density of dwellings and other building construction has resulted } \\
\text { in shading of walls. However, the flat roof spaces are exposed to an } \\
\text { uninterrupted solar radiation regime and this in turn leads to generation of } \\
\text { high sol-air temperatures which cause higher cooling loads. Presently, it } \\
\text { has been argued that roof spaces are one of the major contributors to } \\
\text { building cooling load. } \\
\text { In this article the reasons behind the phenomenal rise in the installation of } \\
\text { air-conditioners in India are reviewed. The dual role of roof-top PV } \\
\text { systems in electricity generation and reduction of building cooling load due } \\
\text { to the shading they provide is then investigated. }\end{array}$ \\
\hline
\end{tabular}

\section{SCHOLARONE \\ Manuscripts}


Installation of roof-top solar PV modules and their impact on building cooling load

\author{
Y. Kotak ${ }^{a}$, E. J. Gago ${ }^{\text {b* }}$, P. Mohanty ${ }^{c}$, T. Muneer ${ }^{d}$ \\ ${ }^{a}$ Edinburgh Napier University, Edinburgh, UK. Email: yashkotak1989@yahoo.com \\ ${ }^{b * U n i v e r s i t y ~ o f ~ G r a n a d a, ~ S p a i n . ~ E m a i l: ~ e j a d r a q u e @ u g r . e s ~}$ \\ ${ }^{\mathrm{C} T h e ~ E n e r g y ~ a n d ~ R e s o u r c e s ~ I n s t i t u t e ~(T E R I), ~ N e w ~ D e l h i, ~ I n d i a . ~ E m a i l: ~ p a r i m i t a @ t e r i . r e s . i n ~}$ \\ ${ }^{d}$ Edinburgh Napier University, Edinburgh, UK. Email: t.muneer@napier.ac.uk
}

\begin{abstract}
It has been shown by many researchers that over a long term there has been a slow but steady rise of ambient temperature within the Indian sub-continent. Due to an increased economic prosperity there has been an accompanied increase in the urban heat island effect. Furthermore, urbanisation of large cities in India has also led to higher population densities. The above factors had the combined effect of a significant increase of cooling load of buildings.
\end{abstract}

The high density of dwellings and other building construction has resulted in shading of walls. However, the flat roof spaces are exposed to an uninterrupted solar radiation regime and this in turn leads to generation of high sol-air temperatures which cause higher cooling loads. Presently, it has been argued that roof spaces are one of the major contributors to building cooling load.

In this article the reasons behind the phenomenal rise in the installation of air-conditioners in India are reviewed. The dual role of roof-top PV systems in electricity generation and reduction of building cooling load due to the shading they provide is then investigated.

\title{
Keywords
}

Climate change, Solar PV modules, Building cooling load, $\mathrm{CO}_{2}$ emissions 


\section{Building Services Engineering Research and Technology}

\section{Introduction}

India lies in the southern portion of Asia. It is a peninsula, surrounded on three sides by water and one side with land. India lies between $8^{\circ} 4^{\prime}$ and $37^{\circ} 6^{\prime}$ North latitude and $68^{\circ} 7^{\prime}$ and $97^{\circ} 25^{\prime}$ East longitude. It covers nearly 2 million square $\mathrm{km}$ of land area. In 2011 the population of India was 1.241 billion with an annual growth rate of $1.37 \%$.

India is a fast growing country with a large economy. India's electricity demand is increasing at the rate of $8.5 \%$. It will be presently shown that large part of the electricity demand in urban areas is due to a phenomenal rise of air-conditioner installations in buildings.

India depends heavily on fossil fuels like coal and oil to meet its rapidly growing energy demand. All major power plants in India are based on thermal systems which provide three fifths of India's energy needs. Amongst the renewable energy sources, India is beginning to exploit solar, wind and biomass technology. Solar energy, however, is the most abundant and stable source of energy available in India, i.e. most parts of India receive $4-7 \mathrm{kWh} / \mathrm{m}^{2}$-day of solar radiation. The development of solar PV technology was initiated in the year 1994 and by early 2013 had reached a cumulative capacity of 1.5 GW. This pales into insignificance though when compared to the UK which has a matching PV capacity with a mere $5 \%$ population ratio and yet an annual solar energy income of $0.9-1.3 \mathrm{kWh} / \mathrm{m}^{2}$ day! There are signs of a vibrant growth in the Indian PV sector though with plants as large as $5 \mathrm{GW}$ planned in the Indian state of Gujarat alone [1]

In the present article, a method for selection of design solar radiation and outdoor ambient temperature for production of sol-air temperature is presented. Design tables for sol-air temperature for five key Indian locations, shown in Fig. 1: Delhi, Bhopal, Ahmadabad, Bhubaneswar and Chennai, are then presented. The production of the latter tables was based on the recently measured data set for solar radiation and ambient temperature that has been made available by the NASA [2] and the India Meteorological Department [3]. Furthermore, those solar radiation, ambient temperature and solair temperature tables were then used to study the impact of the installation of PV modules on rooftops towards sustainable electricity generation and their potential towards the reduction of building cooling load due to the shading provided by the modules.

Insert Figure 1 


\section{The combined impact of climate change, Urban Heat Island effect and economic prosperity on building cooling demand}

\subsection{Climate change}

It has been shown by several researchers $[4,5,6,7,8]$ that over a long term there has been a slow but steady rise of ambient temperature within the Indian sub-continent. Most of the studies have shown that a positive change in temperature with different rates has occurred for different cities within the past century. On the regional scale, Kothawale and Rupa Kumar [9] have examined a surface temperature over India from 1901 to 2003 and reported that annual mean, maximum and minimum temperature had a rise of $0.2^{\circ} \mathrm{C}$ per decade. Sarker and Thapliyal [10] reviewed climate change over the previous 80 years and indicated a warming trend in temperature. The study by Srivastava et al. [11] on decadal trends in climate over India has shown much larger increasing trends of maximum temperatures than the minimum temperatures. Pant and Kumar [12] analysed the data for 1881-1997 and showed that there was a significant warming trend of $0.57^{\circ} \mathrm{C}$ per hundred years. Sinha Ray and De [13] have summarized their work by indicating an increasing trend of $0.35^{\circ} \mathrm{C}$ over the last 100 years. Figure 2 shows the rising trend of annual-averaged maximum, minimum and mean temperature for Chennai which is one of the five locations that are presently under discussion.

Insert Figure 2

\subsection{Urban Heat Island effect}

The phenomenon of Urban Heat Island is recognised as a direct consequence of urbanisation [14, 15, $16,17,18,19,20]$. Urbanisation of large cities in India has also led to higher population densities and rise in temperature $[21,22]$. Indian government backed research has shown that both Delhi and Mumbai, are becoming "urban heat islands", with significantly different climates to their surrounding rural areas. The Delhi-based Energy Research Institute (TERI) has shown that within the past 15 years temperatures in both cities have risen by $2-3^{\circ} \mathrm{C}$. The on-going study, based on NASA [2] satellite readings, also showed the cities to be $5^{\circ} \mathrm{C}-7^{\circ} \mathrm{C}$ warmer than the surrounding rural areas on summer nights [23].

2.3. Rising economic prosperity and the use of air-conditioners 
With one of the fastest growing economies in the world, India recorded an average economic growth rate of $7 \%$ for the period $2000-2003$ [24]. The Indian middle-class population of around 450 million is getting used to an affluent lifestyle.

The Korean air-conditioner manufacturer, LG Electronics claims that in year 2012 India became the world's largest importer of its units. With a present market penetration of a mere $3 \%$ the 2012 recorded sales were 900,000 units and the annual energy consumption for cooling of buildings was 25 TWh [25]. It is not difficult to guess the increase in sales and energy consumption that would take place in the future years once India joins the club of developed countries!

In a landmark article that explores the strong correlation that links the deployment of air-conditioners within homes to economic prosperity and cooling degree-days McNeil and Letschert [26] have provided some interesting data for India. They have shown that with 3,120 cooling degree-days India has the potential capacity to have $99 \%$ market saturation once economic prosperity comes on a par with the western world. The latter work is somewhat flawed though as the base temperature that was used for obtaining cooling degree days was set at $18^{\circ} \mathrm{C}$. The adaptive comfort theory $[27,28]$ suggests that the latter indoor temperature could be as high as $26^{\circ} \mathrm{C}$ for the Indian sub-continent. The personal experience of three of the four authors of this article confirms the latter comfort temperature. However, even with a lower cooling degree-days profile it is evident that there will be an ever increasing deployment of air-conditioners in India.

A further link that has been studied by the above research team is the one between availability of airconditioners and household income and a strong relationship was demonstrated once again. Based on the latter relationship the forecast is a trebling of domestic air-conditioners between the years 2013 and 2030. Figure 3 presents the rising prosperity profile for India.

\section{Insert Figure 3}

The above factors have had the combined effect of a significant increase of cooling load of buildings [29].

\section{Roof-top installation of PV modules}

3.1. Status and trends

India is planning to raise its solar electricity generation capacity by eightfold by the year 2017 [30]. 
In December 2012, Ministry of New \& Renewable Energy (MNRE) [31] released a policy document regarding the next phase of its solar mission. One of the areas that the policy document stresses upon is the rooftop PV segment, with the possible deployment of up to $1 \mathrm{GW}$ of rooftop projects; both for off-grid and grid connected systems. The newly formed Solar Energy Corporation of India (SECI) has started the process to allocate $10 \mathrm{MW}$ of rooftop PV projects in 6 locations - Delhi, Bhubaneswar, Haryana, Chhattisgarh, Karnataka and Tamil Nadu.

Other recent developments include the state of Gujarat that has taken first steps by making its capital, Gandhinagar, a model solar city. By partnering with the private sector, it will generate $5 \mathrm{MW}$ of peak power entirely from Solar PV rooftop system by 2013 and Tamil Nadu which has set a target of $1 \mathrm{GW}$ peak rooftop solar generation from residential and multi-storied housing sector.

Attention may be also drawn to a parallel project that was completed in India's neighbouring country, China where Canadian Solar has completed a 30MW rooftop PV installation in City of Suzhou. The rather large-scale project spanned 129 buildings, with a total surface area of approximately 500,000 square meters. The rooftops were mixed surfaces, with 200,000 square meters of steel structured rooftops and 300,000 square meters of concrete rooftops. The project was completed in June 2013, with full-grid connectivity provided through July and August of the same year. The first year's electricity generation was projected to be over 32GWh/annum [32].

\subsection{Price drop of $P V$ modules}

Figure 4 shows the installed prices for $2-5 \mathrm{~kW}$ capacity PV roof top systems for residential applications in different countries. In India, the price of the equivalent PV system is USD 3,500/kW, which is about the same as the price in China. In Italy, France, Spain and US that price is USD $6,000 / \mathrm{kW}$. Portugal has the highest price at USD 7,000/kW [33].

Insert Figure 4

The Figure 5 shows the historical price reduction of crystalline silicon photovoltaic cells.

Insert Figure 5 [34]

The industry quoted rule seems to be that the cost of photovoltaic cells falls by $20 \%$ with each doubling of global manufacturing capability. 
In April 2013 the present research team completed a design and installation of a complete PV system in Madurai, a city in the Indian state of Tamil Nadu. Figure 6 shows a view of the installed PV modules. The total cost for the $1.5 \mathrm{~kW}$ peak electricity generation and battery storage system was Indian Rupees 294,000 (USD 4,809). This translates to $\$ 3,206 / \mathrm{kWpeak}$.

Insert Figure 6

Presently, with the view to assess the economic viability of rooftop PV system for India a price quote for a complete system was obtained from a local installer. That information is provided in Table 1.

Insert Table 1

\section{Sol-air temperature and building cooling load}

\subsection{Sol-Air Temperature}

Solar radiation absorbed at the outside, opaque surfaces of buildings such as walls and roofs is partly transmitted to the interior of the building. The absorbed radiation has the same effect as a rise in the outside temperature. CIBSE Guide [35] defines the sol-air temperature as the outside temperature which, in the absence of solar radiation, would give the same temperature distribution and rate of energy transfer through the wall or roof as exists with the actual outside air temperature and incident radiation'. The CIBSE Guides A [36] and J [37] provide extensive guidance on estimation method for sol-air temperature, a resume of which is presented below.

For a given amount of cloudiness, $\mathrm{C}$ the horizontal- and vertical surfaces long-wave radiation loss $\left(\mathrm{I}_{\mid \mathrm{w}}, \mathrm{W} / \mathrm{m}^{2}\right)$ are respectively given as,

$I_{|w|}=93-79 C$

Eq. (1)

$\mathrm{I}_{\mathrm{Iwl}}=21-17 \mathrm{C}$

Eq. (2)

The sol-air temperature, $\mathrm{t}_{\mathrm{eo}}$ may then be obtained as follows:

$t_{\text {eo }}=\left(\alpha I_{\text {surface }}-\varepsilon I_{|w|}\right) R_{\text {so }}+t_{\text {ao }}$

where $\alpha$ is the solar absorptance, $I_{\text {surface }}$ the incident solar irradiation $\left(\mathrm{W} / \mathrm{m}^{2}\right), \varepsilon$ the long-wave emissivity, $R_{\mathrm{so}}$ the outside surface resistance $\left(\mathrm{m}^{2}-\mathrm{K} / \mathrm{W}\right)$ and $\mathrm{t}_{\mathrm{ao}}$ the outdoor temperature (Celsius). 
The London based Chartered Institution of Building Services Engineers recommends the use of hourly sol-air temperature tables for cooling load estimation and these are obtained for the design 'maximum' irradiances that are exceeded on $2.5 \%$ of occasions in each month (CIBSE, 2014). The sol-air temperatures are then obtained using coincident dry-bulb temperature. Note that CIBSE recommends $\alpha=0.9$ for dark- and 0.5 for light coloured surfaces and $\varepsilon=0.9$.

\subsection{Building Cooling Load}

This is the rate at which sensible and latent heat must be removed from the space to maintain a constant space air temperature and humidity. Cooling loads result from many conduction, convection, and radiation heat transfer processes through the building envelope and from internal sources and system components. The building components that contribute towards the cooling load may include (a) external walls, roofs, windows, skylights, doors, partitions, ceilings, and floors, (b) internal lights, people, appliances, and equipment, (c) air and moisture leakage or admittance by means of ventilation, and (d) energy transfer from duct leakage, fans and pumps.

The sum of all space instantaneous heat gains at any given time does not necessarily equal the cooling load for the space at that same time. Time delay effects are experienced due to radiant energy absorbed by walls, floor and furniture and re-release as convective gains.

The relevant work of two leading professional bodies that provide guidance on the estimation of building cooling load is briefly mentioned here.

\subsubsection{The work of ASHRAE}

The Atlanta based American Society for Refrigerating, Heating and Air- conditioning Engineers provides extensive guidance on building cooling load estimation. In its most recent edition of Guide to Fundamentals (ASHRAE, 2009) the following two methods are cited.

The 'Heat Balance Method' for obtaining cooling load involves calculating a surface-by-surface conductive, convective, and radiative heat balance for each room surface and a convective heat balance for the room air. The Radiant Time Series (RTS) method is a simplified method for performing design cooling load calculations that is derived from the heat balance method. It replaces the historical 'transfer function' method that was used by ASHRAE for several decades. Figure 7 presents a synopsis of the ASHRAE procedure for obtaining building cooling load. Note that one of the 
essential element in this regard is the knowledge of sol-air temperature for the opaque elements of the building envelope.

\section{Insert Figure 7}

\subsubsection{The work of CIBSE}

Section A5 of CIBSE Guide A provides the algorithmic details for obtaining building cooling load. For the opaque surfaces, the transmission of fluctuations in outdoor sol-air temperature is calculated using a decrement factor ' $f$ ' which is the attenuation of a thermal wave that is travelling through an element of building structure. Thus, if a cyclic wave of amplitude $\lambda$ enters at one side of an element, after a period of $\Phi$ hours a wave of reduced amplitude $f \lambda$ will emerge at the other side. Both ' $f$ ' and $\Phi$ are characteristics of the material and its thickness. Guide A provides tables of properties for construction materials.

\section{Weather data for Indian locations}

5.1. Outdoor temperature and solar radiation NASA-NREL has recently provided hourly global irradiation data for Indian locations that cover the period up to year 2008. Those irradiation values were obtained using Atmospheric Optical Depth (AOD) data set that was in turn developed using satellite data. The latter data sets were compared with ground-truth data from NASA's Aeronet network, and Indian Space Research Organization (ISRO) data made available by the Solar Energy Center (SEC) of India's Ministry for New and Renewable Energy and from additional sites with data published in the literature. The data set presently used in this work for any given month was selected based on completeness of satellite data and performance compared with available ground-truth data.

\subsection{Sol-Air temperature tables for India}

Table 2 provides geographical and other details of the locations under discussion. Using established Statistical Procedures that have been laid out by CIBSE Guide A (2014) and employing the SPSS software time series of daily total irradiation were prepared for each of the five locations from which the 97.5 th percentile value for daily total irradiation and the corresponding date was identified. Table 2 includes the latter information.

Insert Table 2 
Figure 8 shows the plot of Sol-air temperature and its constituting components.

\author{
Insert Figure 8
}

Tables 3 through 7 present Sol-air temperature data for the chosen locations. To date these tables have not been available for any Indian location.

Insert Tables 3, 4, 5, 6, 7

\title{
6. Impact of roof-top PV modules on cooling load
}

As identified in Section 4, availability of hourly irradiation and Sol-air temperature profile for the design day enables estimation of cooling load due to external building fabric. In the present work only the cooling load due to roof has been obtained. Wall induced solar heat load has not been considered in view of the argument presented in Section 5, i.e. wall shading due to a combination of high density of construction and high solar altitude when the sun's intensity is at its peak. The high density of construction for one Delhi suburb is shown in Fig. 9.

\section{Insert Figure 9}

A computer simulation routine was presently developed for solving the classical transient heat conduction problem with hourly Sol-air temperature data and roof construction details provided to the routine. The routine has its roots in an earlier work of one of the present authors [38]. Table 8 and Fig. 10 respectively provide details of the property data and thermal model for the elements of roof construction.

\section{Insert Table 8 and Figure 10}

The problem at hand is a classical one-dimensional heat conduction problem and for computer application may be analysed using a finite-difference method. This method is described in detail in reference [38]. The minimum time increment for the forward-marching scheme in such a case is obtained via Eq. 4,

Fo $(1+\mathrm{Bo}) \leq 0.5$

Eq. (4)

Where Fo is the Fourier number $\left(=\frac{\alpha t}{L c^{2}}\right)$, and Bo is the Biot number $\left(=\frac{h L c}{k}\right)$. The Fourier and Biot number are respectively, the dimensionless time and the ratio of resistance to conduction within the solid to 
surface convective resistance. Note that $\alpha$ is the thermal diffusivity $\left(\frac{m^{2}}{s}\right), L_{c}$ the characteristic length (m), h the surface convection heat transfer coefficient $\left(\frac{W}{m^{2}-K}\right)$ and $\mathrm{k}$ the thermal conductivity $\left(\frac{\mathrm{W}}{m-K}\right)$ of the roof constructional material.

Using the information provided in Table 8 and Figure 10 an optimum time increment for analysing the present transient problem was found to be $120 \mathrm{Sec}$.

The above simulation program was executed to obtain the cooling load profile for each of the five Indian locations for the respective design day. A sample plot of the transient conduction process and the propagation of the thermal wave is shown in Figures 11 and 12 respectively for the case of a conventional, light-coloured flat roof with - and without shading provided by PV modules.

\section{Insert Figures 11 and 12}

In each case a $90 \mathrm{~m}^{2}$ roof area for an average-sized family residence has been used.

Table 9 presents the result obtained from cooling load simulation for the two cases: (a) roof irradiated by sun, and (b) roof shaded by PV array. The reduction in energy required for roof-induced cooling is dramatic as a result of shading, i.e. from $73 \%$ for Chennai to $90 \%$ reduction in energy demand for Delhi. Thus, roof-top PV arrays offer a twin advantage of electricity generation and reduction of energy consumed for roof-induced cooling load.

\section{Insert Table 9}

Table 10 presents further information on the energetic, economic and environmental impact of the proposed roof-top PV array.

\section{Insert Table 10}

Table 11 includes data that has been used for preparation of Table 10.

Insert Table 11 


\section{Discussion}

Reference is made to Figures $11-12$ and Tables 9 - 10. The latter Tables have demonstrated that on one hand, a remarkable reduction of building cooling load can be achieved by roof shading provided by PV modules and on the other hand, a significant energy generation may be achieved. The main contributor to the dual return may be traced to the high solar energy income for the Indian SubContinent. To shed further light Figures 13 and 14 have been prepared. Figure 13 compares the solair temperature profile for Indian location against London, which has a temperate, maritime climate. At peak times, the difference between sol-air temperature for India and London appears to be $26-32$ Celsius. It is a known fact that there is a growing prevalence of the use of air-conditioning for cooling even in London.

\section{Insert Figure 13}

With the above temperature incline for Delhi and other Indian locations, compared to London, it is therefore not surprising to experience a growing demand for cooling. Another point worth mentioning here with respect to Figure 13 is that the coastal locations of Chennai and Bhubaneswar seem to have slighter cooler profile when compared to the remaining three in land locations.

Figure 14 presents the stark difference of the differential between rooftop and outdoor ambient temperature profile for Delhi when compared with London. Whereas a comparatively weak English sun generates a temperature differential of only 13 Celsius, in contract a corresponding Figure of 25 Celsius is noted for Delhi. The sole reason for the above phenomenon is, once again, the high intensity of solar radiation for Delhi.

\section{Insert Figure 14}

Figure 15 presents the Delhi demand profile for the electricity grid. The peak demand occurs around $3 \mathrm{pm}$ when the air-conditioners for offices and residential buildings start to run at full capacity as the thermal wave arrives indoors (see Figure 12). The reported peak load for Delhi on 5th July 2012 was $5.6 \mathrm{GW}$, which occurred at 3pm. [41]. A considerable part of this load may be attributed to cooling of buildings, as the following analysis shall demonstrate.

\section{Insert Figure 15}


Refer to Table 8 that showed Delhi population to be close to 17 million. Being the capital city with a considerable affluence, it may be safely assumed that at least $15 \%$ of the population would use airconditioning. Using a compressor rating of $1.33 \mathrm{~kW}$ for a split system as shown in Table 11 , the cooling load for the city would thus be of the order of over $3 \mathrm{GW}$. The latter load though could be shaved off by $90 \%$ if roof shading was provided as shown in Table 9 .

\section{Conclusions}

The CIBSE method to obtain sol-air temperature with solar radiation and outdoor ambient temperature has been obtained. Design tables for sol-air temperature for five key Indian locations were then obtained. These tables are based on the recently presented data by the NREL-India Meteorological Department consortium. The ambient- and sol-air temperature tables were then used to study the impact of the installation of roof-top PV modules on sustainable electricity generation and their potential towards the reduction of building cooling load due to the shading provided by the PV modules.

A computer simulation routine was presently developed for solving the classical transient heat conduction problem with hourly Sol-air temperature data and roof construction details provided to the routine. This program was executed to obtain the cooling load profile for each of the five Indian locations for the respective design day. The computer simulation demonstrated that the energy required for roof-induced cooling load decreased between $73-90 \%$ after installation of the PV system. The PV system is expected to generate annual solar electricity of at least $11.9 \mathrm{MWh}$ from a 90 square metre roof-top, for each of the five Indian locations.

\section{References}

[1] McDermott M. World's Largest Solar Energy Project (5GW!) Planned for Gujarat, India. Energy/Renewable Energy. August 11, 2008. http://www.treehugger.com/renewableenergy/worldatms-largest-solar-energy-project-5gw-planned-for-gujarat-india.html.

[2] http://www.nasa.gov/.

[3] Indian Meteorological Department. Ministry of Earth Sciences. Govt of India. http://www.imd.gov.in/.

[4] Deosthali V. Impact of rapid urban growth on heat and moisture islands in Pune City, India. Atmos Environ 2000; 34: 2745-54. 
1

2

3

4

5

6

7

8

9

[5] Badarinath KVS, Kiran Chand TR, Madhavi Latha K, Raghavaswamy V. Studies on urban heat islands using ENVISAT AATSR data. J Indian Soc Remote Sens 2005; 33: 495-501.

[6] Mallick J, Kant Y, Bharath BD. Estimation of land surface temperature over Delhi using Landsat-7 ETM+. J Ind Geophys Union 2008; 12: 131-40.

[7] Kamal WA. Improving energy efficiency-the cost-effective way to mitigate global warming. Energy Convers. Mgmt 1997; 38 (1): 39-59.

[8] Raghuvanshi SP, Chandra A, Raghav AK. Carbon dioxide emissions from coal based power generation in India. Energy Conversion and Management 2006; 47: 427-441.

[9] Kothawale DR, Kumar KR. Tropospheric temperature variation over India and links with the Indian summer monsoon: 1971-2000, Mausam 2002; 53: 289-308.

[10] Sarker RP, Thapliyal V. Climate change and variability, Mausam. 1988; 39: 127-138.

[11] Srivastava HN, Dewan BN, Dikshit SK, Rao PGS, Singh SS, Rao KR. Decadal trends in climate over India, Mausam. 1992; 43: 7-20.

[12] Pant GB, Kumar KR. Climates of South Asia. John Wiley. Chichester, UK, 1997.

[13] Sinha Ray KC, De US. Climate change in India as evidenced from instrumental records. WMO Bull. 2003; 52: 53-59.

[14] Radhi H, Fikry F, Sharples S. Impacts of urbanisation on the thermal behaviour of new built up environments: A scoping study of the urban heat island in Bahrain. Landscape and Urban Planning 2013; 113: 47-61.

[15] Cui L, Shi J. Urbanization and its environmental effects in Shanghai, China. Urban Climate 2012; 2: $1-15$.

[16] Hung T, Uchihama D, Ochi S, Yasuoka Y. Assessment with satellite data of the urban heat island effects in Asian mega cities. International Journal of Applied Earth Observation and Geoinformation 2006; 8: 34-48.

[17] Kapsomenakis J, Kolokotsa D, Nikolaou T, Santamouris M, Zerefos SC. Forty years increase of the air ambient temperature in Greece: The impact on buildings. Energy Conversion and Management 2013; 74: 353-365.

[18] Mavrogianni A, Davies M, Batty M, Belcher SE, Bohnenstengel SI, Carruthers D, Chalabi Z, Croxford B, Demanuele C, Evans S, Giridharan R, Hacker JN, Hamilton I, Hogg C, Hunt J, Kolokotroni M, Martin C, Milner J, Rajapaksha I, Ridley I, Steadman JP, Stocker J, Wilkinson P, Ye Z. 
The comfort, energy and health implications of London's urban heat island. Building Serv. Eng. Res. Technol. 2011; 32 (1): 35-52.

[19] Lee SE, Levermore GJ. Simulating urban heat island effects with climate change on a Manchester house. Building Serv. Eng. Res. Technol. 34(2): 203-221.

[20] Kershaw T, Sanderson M, Coley D, Eames M. Estimation of the urban heat island for UK climate change projections. Building Serv. Eng. Res. Technol. 2010; 31 (3): 251-263.

[21] Subbiah S, Vishwanath V, Kaveri Devi S. Urban Climate in Tamil Nadu, India: A Statistical Analysis of Increasing Urbanization and Changing Trends of Temperature and Rainfall. Energy and Buildings 1990/91; (15 - 16): 231 - 243.

[22] Vidal J, Pathak S. How urban heat islands are making India hotter. The Guardian, January 9 2013. http://www.guardian.co.uk/global-development/poverty-matters/2013/ian/09/delhimumbai-urban-heat-islands-india.

[23] TERI Press. The Energy and Resources Institute, 2009. ISBN 978-81-7993-222-3. http://www.teriin.org/index.php.

[24] http://en.wikipedia.org/wiki/Standard_of_living_in_India.

[25] Mamgain P, Bureau ET. India to be LG's largest AC market in 2012: Sewoo Park, February 4 2011. http://articles.economictimes.indiatimes.com/2011-02-04/news/28431286_1_ac-pricesmarketshare-india.

[26] McNeil MA, Letschert VE. Developing Countries and what can be done about it: The Potential of Efficiency in the Residential Sector. http://escholarship.org/uc/item/64f9r6wr

[27] Nicol F, Raja I. Thermal comfort, time and posture: exploratory studies in the nature of adaptive thermal comfort. Oxford: School of Architecture, Oxford Brokes University. 1996.

[28] Humphreys MA. The dependence of comfortable temperature upon indoor and outdoor climate in Cena K and Clark J A (eds.) Bioengineering, Thermal Physiology and Comfort. Oxford: Elsevier. 1981.

[29] Akpinar-Ferrand E, Singh A. Modeling increased demand of energy for air conditioners and consequent $\mathrm{CO}_{2}$ emissions to minimize health risks due to climate change in India. Environmental science \& policy 2013; 13: 702-712.

[30] Chaudhary A. India to Auction Unsold Rooftop Solar Projects Across 7 Cities, Apr 5, 2013.

http://mc.manuscriptcentral.com/bsert 
[31] Ministry of New \& Renewable Energy, Jawaharlal Nehru National Solar Mission, Phase II-Policy Document, December 2012. http://mnre.gov.in/file-manager/UserFiles/draft-jnnsmpd-2.pdf.

[32] Canadian Solar Inc., Canadian Solar Successfully Completed 30 MW Rooftop PV Installations in Suzhou, China, July 25 2013. www.canadiansolar.com.

[33] Irena 2012. Renewable energy technologies: cost analysis series. Volume 1: Power Sector. Issue 4/5. June 2012.

[34] Carr G. Pricing sunshine. The rise of solar energy, Dec 28, 2012. http://www.economist.com/blogs/graphicdetail/2012/12/daily-chart-19>

[35] https://www.cibseknowledgeportal.co.uk/cibse-guides.

[36] Guide A: Environmental Design. CIBSE. pp. 323. 2006.

[37] Guide J: Weather, Solar and Illuminance Data (CD-ROM) (CIBSE Guide J). CIBSE. pp. 455. 2002.

[38] Muneer T, Kubie J, Grassie T, Heat transfer: a problem solving approach, Taylor \& Francis, London, 2002.

[39] Ananthapadmanabhan G, Srinivas K, Gopal V. Hiding. Behind the poor. A report by Greenpeace on Climate injustice. October 2007.

[40] Trane, Packaged Terminal Air Conditioners \& Heat Pumps, October 2000. http://www.trane.com/download/equipmentpdfs/ptacprc001en.pdf.

[41] The Times of India. Power demand nears 6,000 MW. Jul 6, 2102. http://articles.timesofindia.indiatimes.com/2012-07-06/delhi/32565338_1_power-demand-maximumdemand-power-department-officials. 


\section{List of Tables}

1. Price quote for roof-top PV system for India.

2. Locations chosen for the present study.

3. Sol-air temperature table for Delhi (based on CIBSE recommended $97.5^{\text {th }}$ percentile daily radiation method).

4. Sol-air temperature table for Bhopal (based on CIBSE recommended $97.5^{\text {th }}$ percentile daily radiation method).

5. Sol-air temperature table for Ahmadabad (based on CIBSE recommended $97.5^{\text {th }}$ percentile daily radiation method).

6. Sol-air temperature table for Bhubaneswar (based on CIBSE recommended $97.5^{\text {th }}$ percentile daily radiation method).

7. Sol-air temperature table for Chennai (based on CIBSE recommended $97.5^{\text {th }}$ percentile daily radiation method).

8. Thermo-physical data for roof construction material used in India.

9. Roof induced cooling load (kWh) for a $97.5^{\text {th }}$ percentile day

10. Energetic, economic and environmental impact of the proposed roof-top PV array.

11. Data required for preparing Table 10. 
2

Table 1

Price quote for roof-top PV system for India

\begin{tabular}{|l|r|r|r|}
\hline \multicolumn{1}{|c|}{ Component } & Cost, INR & \multicolumn{1}{c|}{ Cost, USD } & Ratio of total system cost \\
\hline Monocrystalline modules & 350,000 & 5,600 & 0.44 \\
\hline 5kVA grid tied inverter & 250,000 & 4,000 & 0.31 \\
\hline Cables and module support & 100,000 & 1,600 & 0.13 \\
\hline Transportation and installation & 100,000 & 1,600 & 0.13 \\
\hline Total cost & 800,000 & 12,800 & \\
\hline
\end{tabular}

Note: Modules cost $=\$ 1.4 / \mathrm{Wp}$ and system cost $=\$ 3.2 / \mathrm{Wp}$

INR = Indian Rupee, USD = US Dollar

Table 2

Locations chosen for the present study

\begin{tabular}{|l|l|r|r|r|}
\hline \multicolumn{1}{|c|}{ Location (city) } & \multicolumn{1}{c|}{ State } & Latitude, N & \multicolumn{1}{c|}{$\begin{array}{c}\text { Longitude, } \\
\text { E }\end{array}$} & $\begin{array}{c}\text { State population, 2011 } \\
\text { Census }\end{array}$ \\
\hline Delhi & Delhi & 29.02 & 77.38 & $16,753,235$ \\
\hline Bhopal & $\begin{array}{l}\text { Madhya } \\
\text { Pradesh }\end{array}$ & 23.25 & 77.42 & $72,597,565$ \\
\hline Ahmedabad & Gujarat & 23.03 & 72.62 & $60,383,628$ \\
\hline Bhubaneshwar & Odisha & 20.27 & 85.84 & $41,947,358$ \\
\hline Chennai & Tamil Nadu & 13.08 & 80.27 & $72,138,958$ \\
\hline
\end{tabular}


Table 3

Sol-air temperature table for Delhi (based on CIBSE recommended 97.5 percentile daily radiation method)

\begin{tabular}{|r|r|r|r|}
\hline \multicolumn{1}{|c|}{$\begin{array}{c}\text { Time, } \\
\text { hour }\end{array}$} & $\begin{array}{c}\text { Radiation, } \\
\mathbf{W} / \mathbf{m}^{2}\end{array}$ & $\begin{array}{c}\text { Ambient temperature, } \\
\mathbf{C}\end{array}$ & $\begin{array}{c}\text { Sol-air temperature, } \\
\mathbf{C}\end{array}$ \\
\hline 0 & 0 & 23.8 & 18.0 \\
\hline 1 & 0 & 23.1 & 17.3 \\
\hline 2 & 0 & 22.6 & 16.7 \\
\hline 3 & 0 & 22.1 & 16.3 \\
\hline 4 & 0 & 22.0 & 16.1 \\
\hline 5 & 0 & 22.3 & 16.4 \\
\hline 6 & 88 & 23.0 & 20.2 \\
\hline 7 & 288 & 24.2 & 28.5 \\
\hline 8 & 491 & 26.1 & 37.4 \\
\hline 9 & 702 & 28.2 & 46.9 \\
\hline 10 & 866 & 30.5 & 55.0 \\
\hline 11 & 960 & 32.8 & 60.5 \\
\hline 12 & 977 & 34.5 & 62.8 \\
\hline 13 & 938 & 35.6 & 62.6 \\
\hline 14 & 845 & 36.0 & 59.7 \\
\hline 15 & 670 & 35.6 & 53.2 \\
\hline 16 & 462 & 34.6 & 44.9 \\
\hline 17 & 255 & 33.1 & 36.1 \\
\hline 18 & 65 & 31.2 & 27.7 \\
\hline 19 & 0 & 29.4 & 23.6 \\
\hline 20 & 0 & 27.9 & 22.0 \\
\hline 21 & 0 & 26.5 & 20.6 \\
\hline 22 & 0 & 25.4 & 19.5 \\
\hline 23 & 0 & 24.5 & 18.7 \\
\hline
\end{tabular}


Table 4

Sol-air temperature table for Bhopal (based on CIBSE recommended 97.5 percentile daily radiation method)

\begin{tabular}{|c|c|c|c|}
\hline $\begin{array}{l}\text { Time, } \\
\text { hour }\end{array}$ & $\begin{array}{l}\text { Radiation, } \\
\mathrm{W} / \mathrm{m}^{2}\end{array}$ & $\begin{array}{c}\text { Ambient temperature, } \\
\text { C }\end{array}$ & $\begin{array}{c}\text { Sol-air temperature, } \\
\text { C }\end{array}$ \\
\hline 0 & 0 & 28.0 & 22.2 \\
\hline 1 & 0 & 27.2 & 21.4 \\
\hline 2 & 0 & 26.6 & 20.8 \\
\hline 3 & 0 & 26.2 & 20.3 \\
\hline 4 & 0 & 26.0 & 20.1 \\
\hline 5 & 0 & 26.3 & 20.5 \\
\hline 6 & 73 & 27.1 & 23.8 \\
\hline 7 & 291 & 28.5 & 32.8 \\
\hline 8 & 527 & 30.5 & 43.1 \\
\hline 9 & 724 & 32.8 & 52.3 \\
\hline 10 & 879 & 35.5 & 60.4 \\
\hline 11 & 975 & 38.0 & 66.2 \\
\hline 12 & 1006 & 39.8 & 69.2 \\
\hline 13 & 964 & 41.1 & 69.0 \\
\hline 14 & 863 & 41.6 & 65.9 \\
\hline 15 & 698 & 41.1 & 59.7 \\
\hline 16 & 491 & $x^{2}=2$ & 51.3 \\
\hline 17 & 258 & 38.3 & 41.5 \\
\hline 18 & 47 & 36.3 & 32.0 \\
\hline 19 & 0 & 34.2 & 28.4 \\
\hline 20 & 0 & 32.5 & 26.7 \\
\hline 21 & 0 & 31.0 & 25.1 \\
\hline 22 & 0 & 29.7 & 23.9 \\
\hline 23 & 0 & 28.8 & 22.9 \\
\hline
\end{tabular}


Table 5

Sol-air temperature table for Ahmadabad (based on CIBSE recommended 97.5 percentile daily radiation method)

\begin{tabular}{|r|r|r|r|}
\hline \multicolumn{1}{c|}{$\begin{array}{c}\text { Time, } \\
\text { hour }\end{array}$} & $\begin{array}{c}\text { Radiation, } \\
\mathbf{W} / \mathbf{m}^{\mathbf{2}}\end{array}$ & $\begin{array}{c}\text { Ambient temperature, } \\
\mathbf{C}\end{array}$ & $\begin{array}{c}\text { Sol-air temperature, } \\
\mathbf{C}\end{array}$ \\
\hline 0 & 0 & 29.5 & 23.7 \\
\hline 1 & 0 & 28.8 & 23.0 \\
\hline 2 & 0 & 28.3 & 22.4 \\
\hline 3 & 0 & 27.8 & 22.0 \\
\hline 4 & 0 & 27.7 & 21.8 \\
\hline 5 & 0 & 28.0 & 22.1 \\
\hline 6 & 28 & 28.7 & 23.8 \\
\hline 7 & 226 & 30.0 & 32.0 \\
\hline 8 & 453 & 31.8 & 41.8 \\
\hline 9 & 661 & 33.9 & 51.2 \\
\hline 10 & 837 & 36.4 & 59.8 \\
\hline 11 & 954 & 38.6 & 66.2 \\
\hline 12 & 1004 & 40.3 & 69.6 \\
\hline 13 & 984 & 41.5 & 70.1 \\
\hline 14 & 895 & 41.9 & 67.4 \\
\hline 15 & 745 & 41.5 & 61.7 \\
\hline 16 & 546 & 40.5 & 53.7 \\
\hline 17 & 321 & 38.9 & 44.3 \\
\hline 18 & 100 & 37.1 & 34.7 \\
\hline 19 & 0 & 35.2 & 29.4 \\
\hline 20 & 0 & 33.7 & 27.8 \\
\hline 21 & 0 & 32.2 & 26.4 \\
\hline 22 & 0 & 31.1 & 25.2 \\
\hline 23 & 0 & 30.3 & 24.4 \\
\hline
\end{tabular}


Table 6

Sol-air temperature table for Bhubaneswar (based on CIBSE recommended 97.5 percentile daily radiation method)

\begin{tabular}{|r|r|r|r|}
\hline \multicolumn{1}{c|}{$\begin{array}{c}\text { Time, } \\
\text { hour }\end{array}$} & $\begin{array}{c}\text { Radiation, } \\
\mathbf{W} / \mathbf{m}^{\mathbf{2}}\end{array}$ & $\begin{array}{c}\text { Ambient temperature, } \\
\mathbf{C}\end{array}$ & $\begin{array}{c}\text { Sol-air temperature, } \\
\mathbf{C}\end{array}$ \\
\hline 0 & 0 & 26.3 & 20.4 \\
\hline 1 & 0 & 25.6 & 19.8 \\
\hline 2 & 0 & 25.1 & 19.3 \\
\hline 3 & 0 & 24.8 & 18.9 \\
\hline 4 & 0 & 24.7 & 18.8 \\
\hline 5 & 1 & 24.9 & 19.1 \\
\hline 6 & 125 & 25.5 & 24.0 \\
\hline 7 & 399 & 26.6 & 34.7 \\
\hline 8 & 622 & 28.2 & 44.2 \\
\hline 9 & 809 & 30.1 & 52.6 \\
\hline 10 & 940 & 32.2 & 59.3 \\
\hline 11 & 1000 & 34.2 & 63.3 \\
\hline 12 & 929 & 35.7 & 62.3 \\
\hline 13 & 850 & 36.7 & 60.6 \\
\hline 14 & 733 & 37.1 & 56.8 \\
\hline 15 & 556 & 36.7 & 50.3 \\
\hline 16 & 330 & 35.8 & 41.5 \\
\hline 17 & 91 & 34.4 & 31.8 \\
\hline 18 & 0 & 32.8 & 27.0 \\
\hline 19 & 0 & 31.2 & 25.4 \\
\hline 20 & 0 & 29.9 & 24.0 \\
\hline 21 & 0 & 28.6 & 22.8 \\
\hline 22 & 0 & 27.6 & 21.8 \\
\hline 23 & 0 & 26.9 & 21.0 \\
\hline
\end{tabular}


Table 7

Sol-air temperature table for Chennai (based on CIBSE recommended 97.5 percentile daily radiation method)

\begin{tabular}{|c|c|c|c|}
\hline $\begin{array}{l}\text { Time, } \\
\text { hour }\end{array}$ & $\begin{array}{l}\text { Radiation, } \\
\mathrm{W} / \mathrm{m}^{2}\end{array}$ & $\begin{array}{c}\text { Ambient temperature, } \\
\text { C }\end{array}$ & $\begin{array}{c}\text { Sol-air temperature, } \\
\text { C }\end{array}$ \\
\hline 0 & 0 & 30.0 & 24.2 \\
\hline 1 & 0 & 29.4 & 23.5 \\
\hline 2 & 0 & 28.9 & 23.0 \\
\hline 3 & 0 & 28.5 & 22.7 \\
\hline 4 & 0 & 28.4 & 22.5 \\
\hline 5 & 0 & 28.7 & 22.8 \\
\hline 6 & 61 & 29.3 & 25.6 \\
\hline 7 & 282 & 30.4 & 34.4 \\
\hline 8 & 521 & 32.0 & 44.4 \\
\hline 9 & 722 & 33.9 & 53.3 \\
\hline 10 & 874 & 36.1 & 60.8 \\
\hline 11 & 963 & 38.1 & 65.9 \\
\hline 12 & 978 & 39.6 & 67.9 \\
\hline 13 & 919 & 40.6 & 66.9 \\
\hline 14 & 792 & 41.0 & 62.8 \\
\hline 15 & 609 & 40.6 & 56.0 \\
\hline 16 & 390 & 39.7 & 47.5 \\
\hline 17 & 149 & 38.3 & 37.7 \\
\hline 18 & 0 & 36.7 & 30.8 \\
\hline 19 & 0 & 35.1 & 29.2 \\
\hline 20 & 0 & 33.7 & 27.8 \\
\hline 21 & 0 & 32.4 & 26.6 \\
\hline 22 & 0 & 31.4 & 25.6 \\
\hline 23 & 0 & 30.7 & 24.8 \\
\hline
\end{tabular}

Table 8

Thermo-physical data for roof construction material used in India

\begin{tabular}{|l|r|r|r|r|}
\hline \multicolumn{1}{|c|}{ Element } & \multicolumn{1}{|c|}{$\begin{array}{c}\text { Density, } \\
\mathbf{k g} / \mathbf{m}^{\mathbf{3}}\end{array}$} & $\begin{array}{c}\text { Specific Heat, } \\
\text { J/kg-K }\end{array}$ & $\begin{array}{c}\text { Thermal } \\
\text { Conductivity, } \\
\mathbf{W} / \mathbf{m}-\mathbf{K}\end{array}$ & $\begin{array}{c}\text { Thermal Diffusivity, } \\
\mathbf{~ m}^{\mathbf{2} / \mathbf{s}}\end{array}$ \\
\hline Cement mortar & 1860 & 780 & 0.72 & $4.96 \mathrm{E}-07$ \\
\hline Common brick & 1920 & 835 & 0.72 & $4.49 \mathrm{E}-07$ \\
\hline Reinforced concrete & 2000 & 880 & 1.37 & $7.78 \mathrm{E}-07$ \\
\hline
\end{tabular}


Table 9

Roof induced cooling load (kWh) for a $97.5^{\text {th }}$ percentile day

\begin{tabular}{|l|r|r|r|r|r|}
\hline & \multicolumn{1}{|c|}{ Delhi } & Bhopal & Ahmadabad & Bhubaneswar & \multicolumn{1}{c|}{ Chennai } \\
\hline Roof irradiated by sun & 33.2 & 45.3 & 46.8 & 37.4 & 45.3 \\
\hline $\begin{array}{l}\text { Roof shaded by PV } \\
\text { array }\end{array}$ & 3.4 & 10.5 & 12.4 & 5.8 & 12.3 \\
\hline
\end{tabular}

Table 10

Energetic, economic and environmental impact of the proposed roof-top PV array

\begin{tabular}{|l|l|l|l|}
\hline \multicolumn{1}{|c|}{ Location } & \multicolumn{1}{|c|}{$\begin{array}{c}\text { Annual solar electricity output, } \\
\text { kWh }\end{array}$} & $\begin{array}{c}\text { Income, } \\
\text { USD }\end{array}$ & $\begin{array}{c}\mathbf{C O}_{2} \text { Emission Saved, } \\
\text { Tonnes [39] }\end{array}$ \\
\hline Delhi & 13011 & 1041 & 11320 \\
\hline Bhopal & 12421 & 994 & 10806 \\
\hline Ahmadabad & 12722 & 1018 & 11068 \\
\hline Bhubaneswar & 11920 & 954 & 10371 \\
\hline Chennai & 12383 & 991 & 10773 \\
\hline
\end{tabular}

*Income = energy sold to grid per annum

Table 11

Data required for preparing Table 10

\begin{tabular}{|l|r|}
\hline $\mathrm{COP}_{\text {cooling }}[40]$ & 2.8 \\
\hline $\mathrm{Q}_{\text {evaporation }}$ & $3.73 \mathrm{~kW}$ \\
\hline Design outdoor temperature $\left({ }^{\circ} \mathrm{C}\right)$ & $40.5-46$ \\
\hline $\mathrm{W}_{\text {compressor }}(\mathrm{kW})$ & 1.33 \\
\hline Design indoor dry bulb temperature $\left({ }^{\circ} \mathrm{C}\right)$ & 24 \\
\hline Design indoor wet bulb temperature $\left({ }^{\circ} \mathrm{C}\right)$ & 19.4 \\
\hline
\end{tabular}




\section{List of Figures}

1. Five Indian locations chosen for this study.

2. The rising trend of annual-averaged maximum, minimum and mean temperature for Chennai, India. Note: Temperature in Celsius scale.

3. The rising Purchasing Power Parity, PPP (US Dollars) for India.

4. Installed prices for 2-5 kW PV roof-top system for residential applications in different countries, 2010 data.

5. The decreasing cost of crystalline silicon photovoltaic cells.

6. Rootop without-and with PV modules for a building in Madurai, India.

7. ASHRAE building cooling load calculation method.

8. Hourly Sol-air temperature for Delhi for the design day.

9. Delhi suburb plan view showing the high density of residences.

10. Thermal model presently developed for roof heat load under transient conduction.

11. Thermal wave propagation for a flat roof under shade provided by a $7 \mathrm{kWp}$ array. Note: The thermal loading in this case is due to outdoor-indoor temperature difference.

12. Thermal wave propagation for a flat irradiated roof. Note: The thermal loading in this case is due to outdoor-indoor temperature difference.

13. Inter-comparison of flat roof solar-air temperature (Celsius) for Indian locations and London.

14. Demonstration of the flat roof sol-air and outdoor ambient temperature differential (Celsius) for Delhi and London.

15. Typical electricity demand profile for the month of July for Delhi grid. 


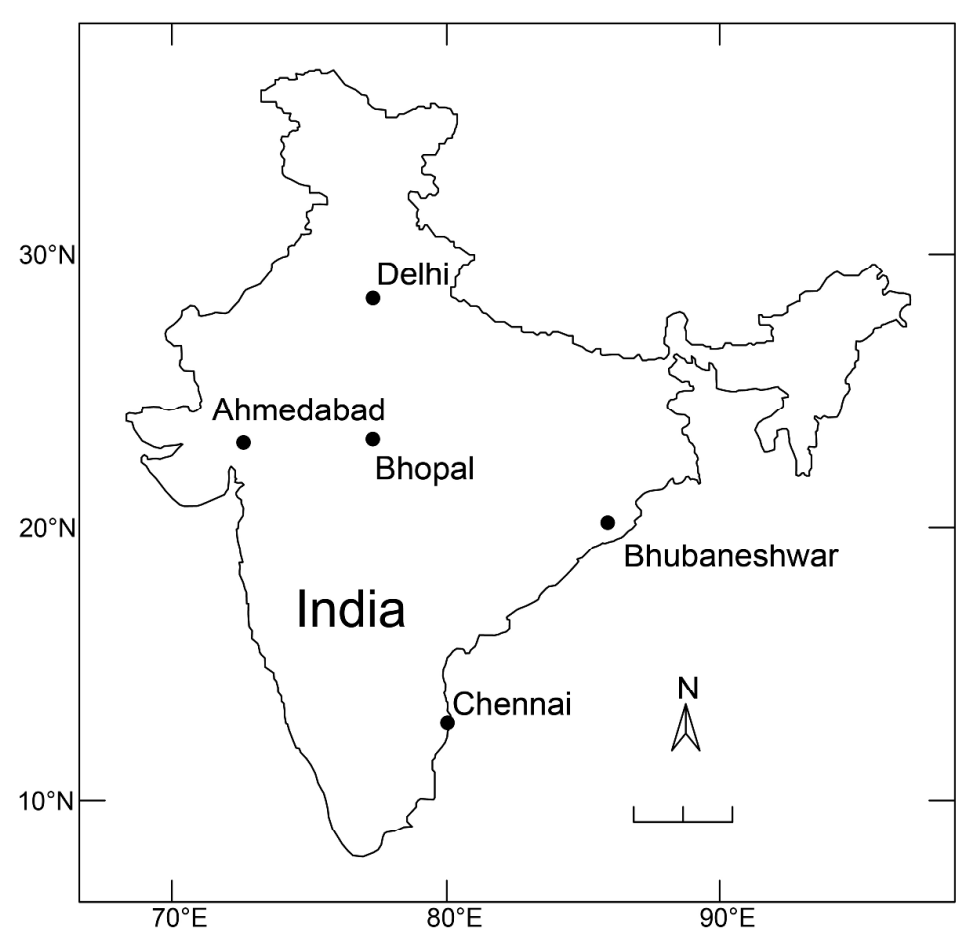

Fig. 1. Five Indian locations chosen for this study.

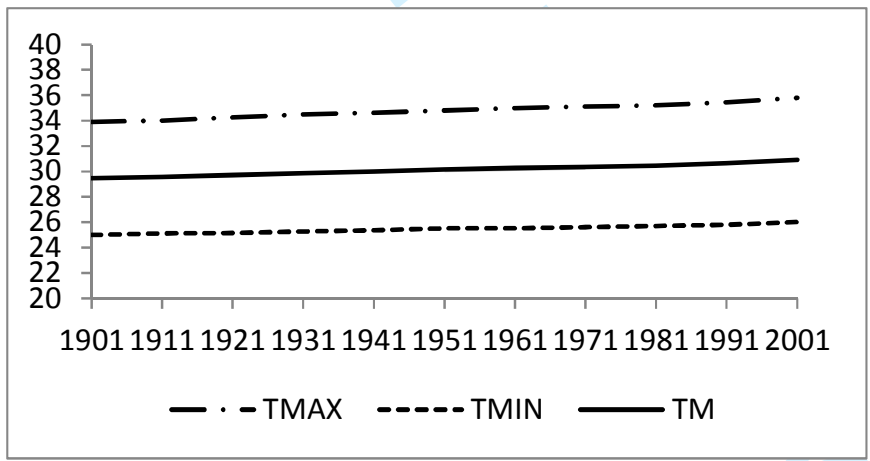

Fig. 2. The rising trend of annual-averaged maximum, minimum and mean temperature for Chennai, India. Note: Temperature in Celsius scale. 


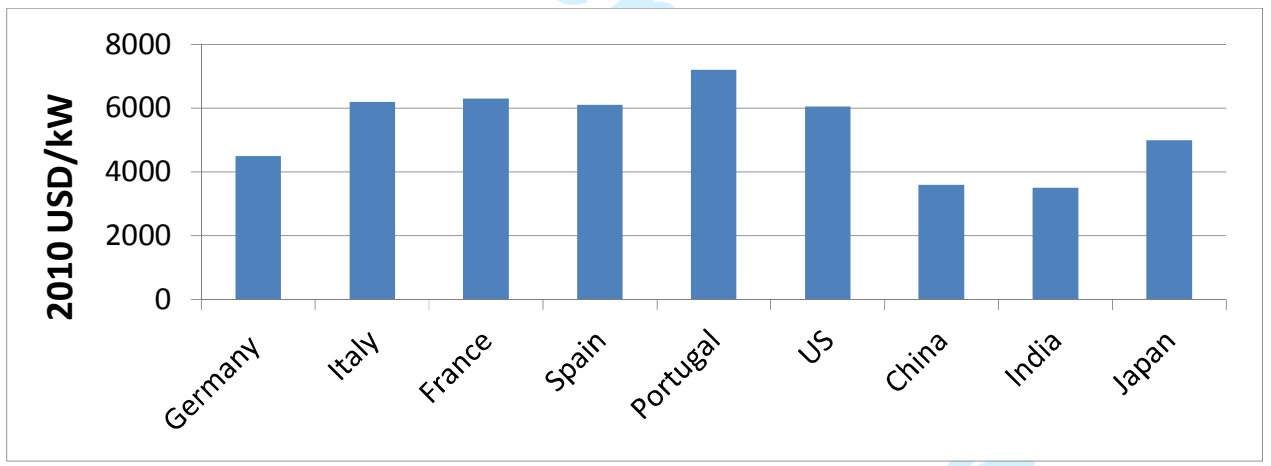

Fig. 4. Installed prices for 2-5 kW PV roof-top system for residential applications in different countries, 2010 data. 


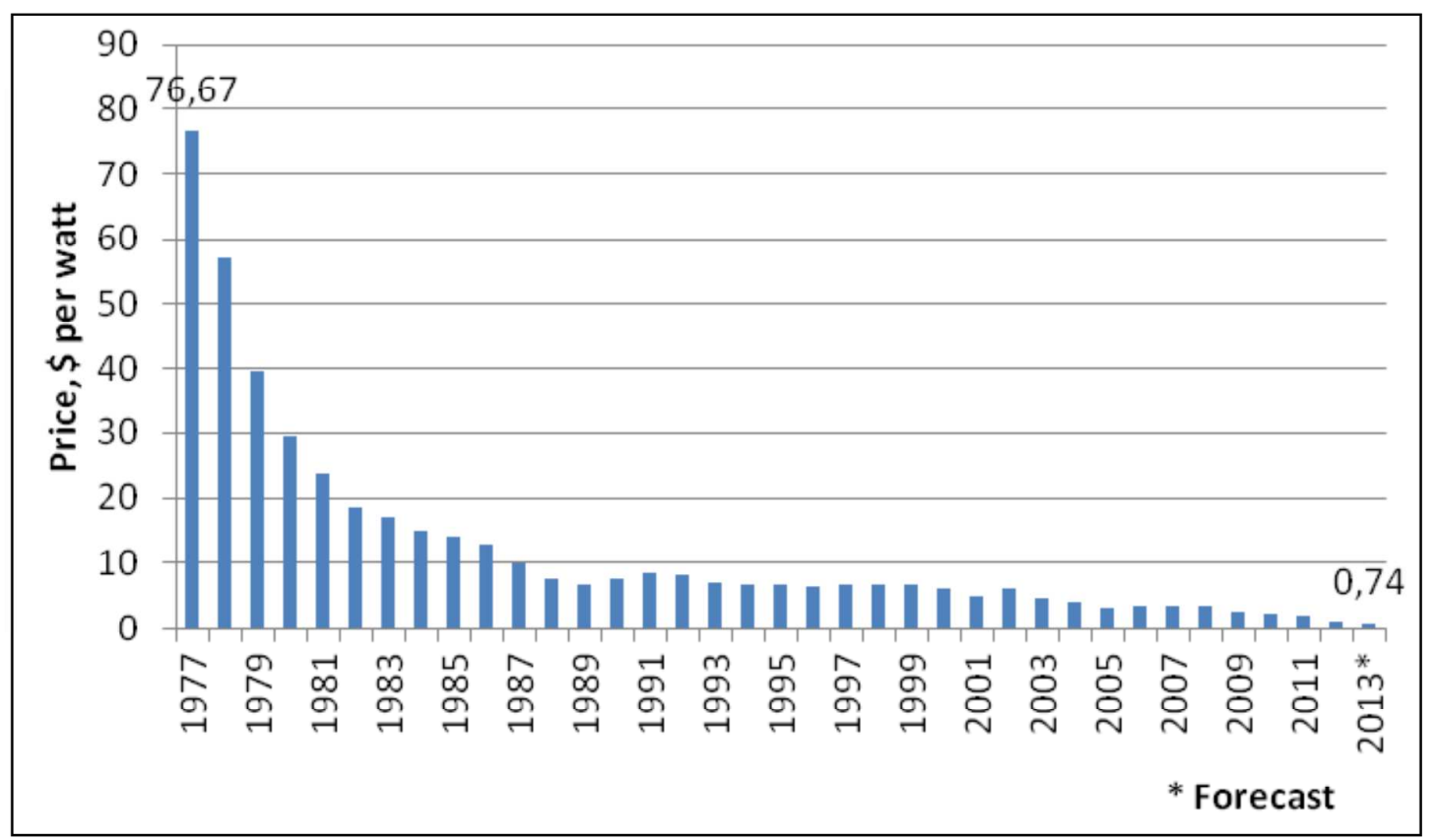

Fig. 5. The decreasing cost of crystalline silicon photovoltaic cells.
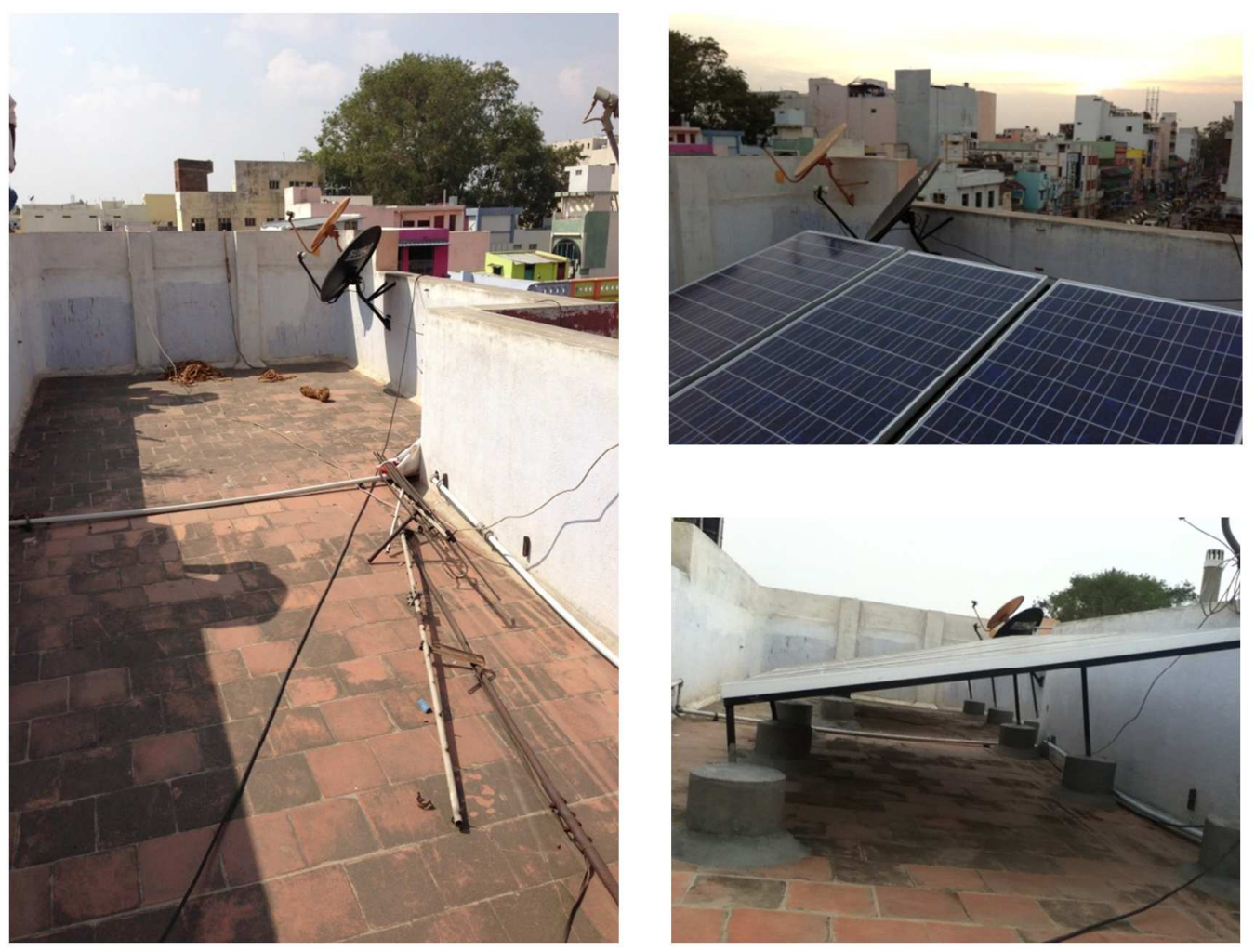

Fig.6. Rootop without-and with PV modules for a building in Madurai, India. 


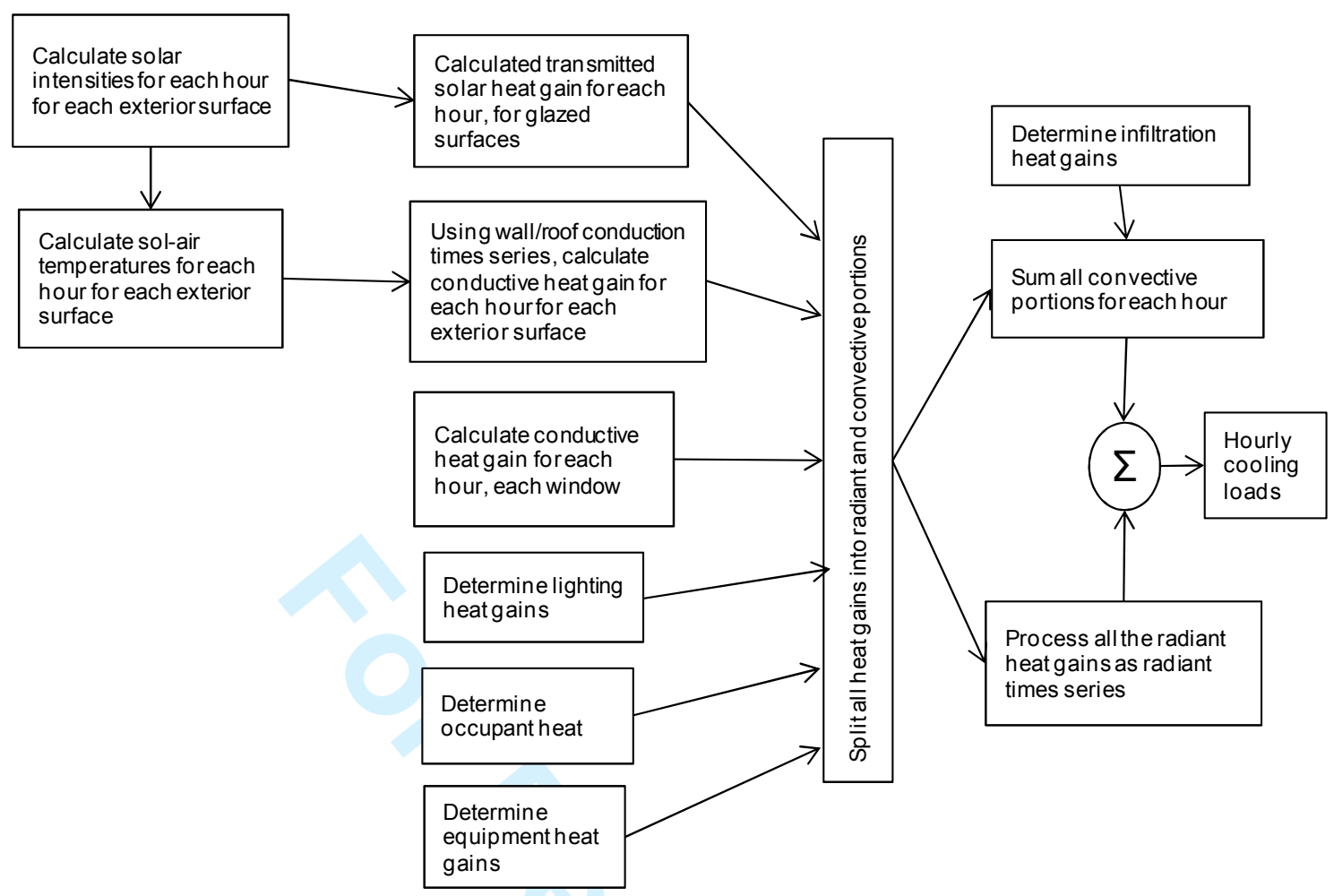

Fig.7. ASHRAE building cooling load calculation method.

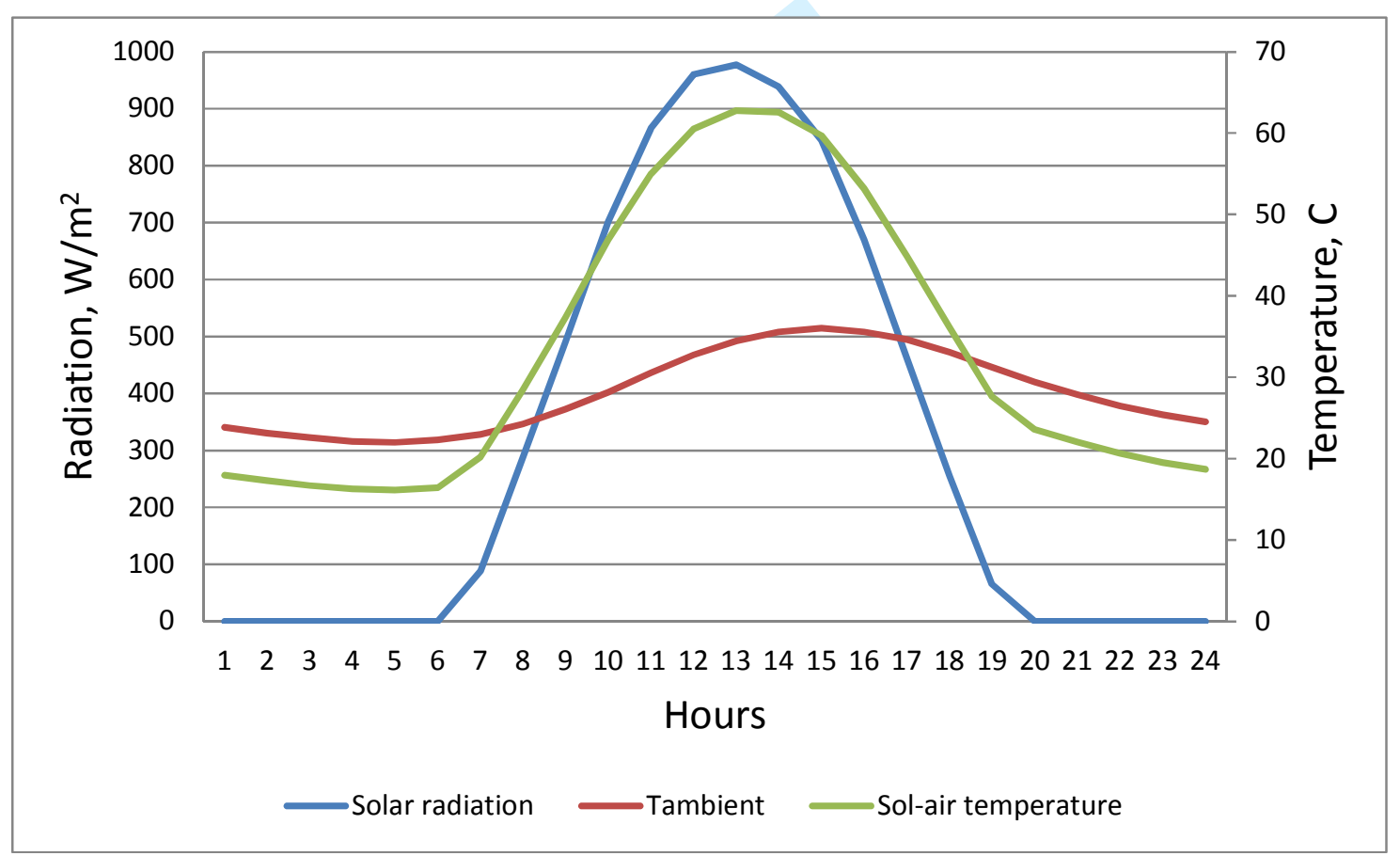

Fig.8. Hourly Sol-air temperature for Delhi for the design day. 


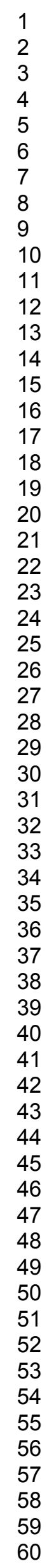

Fig.9. Delhi suburb plan view showing the high density of residences.

http://mc.manuscriptcentral.com/bsert 
Fig.10. Thermal model presently developed for roof heat load under transient conduction.

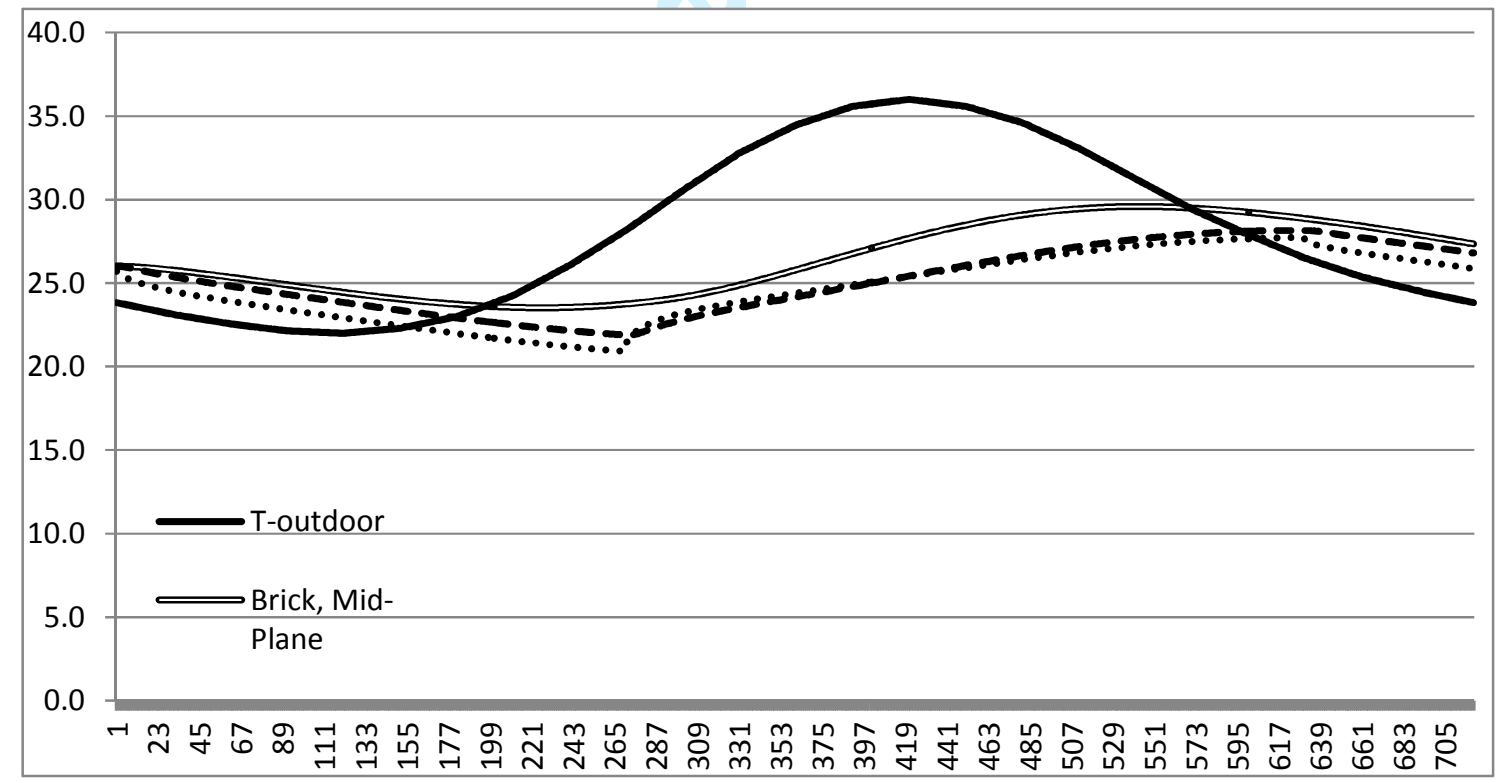

Fig.11. Thermal wave propagation for a flat roof under shade provided by a $7 \mathrm{kWp}$ array. Note: The thermal loading in this case is due to outdoor-indoor temperature difference. 


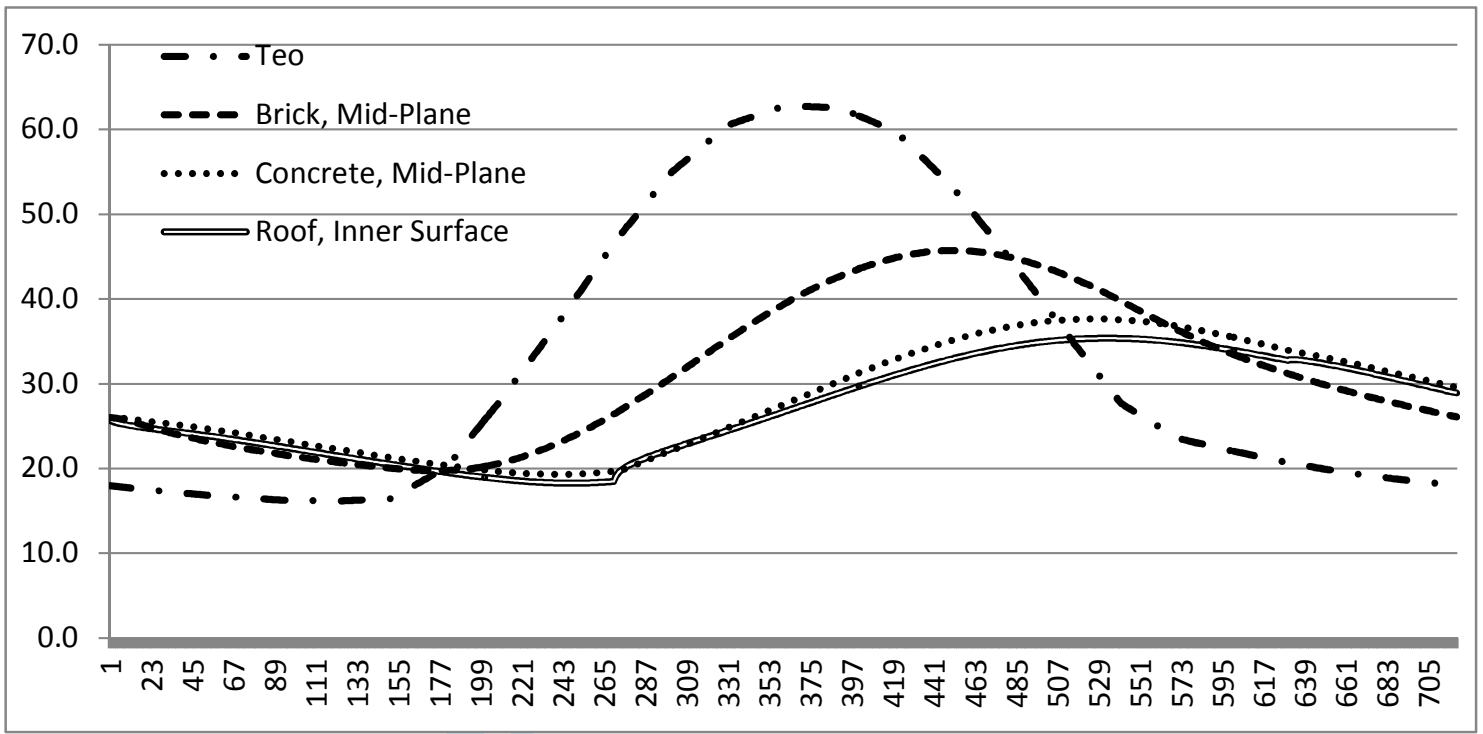

Fig.12. Thermal wave propagation for a flat irradiated roof. Note: The thermal loading in this case is due to outdoor-indoor temperature difference.

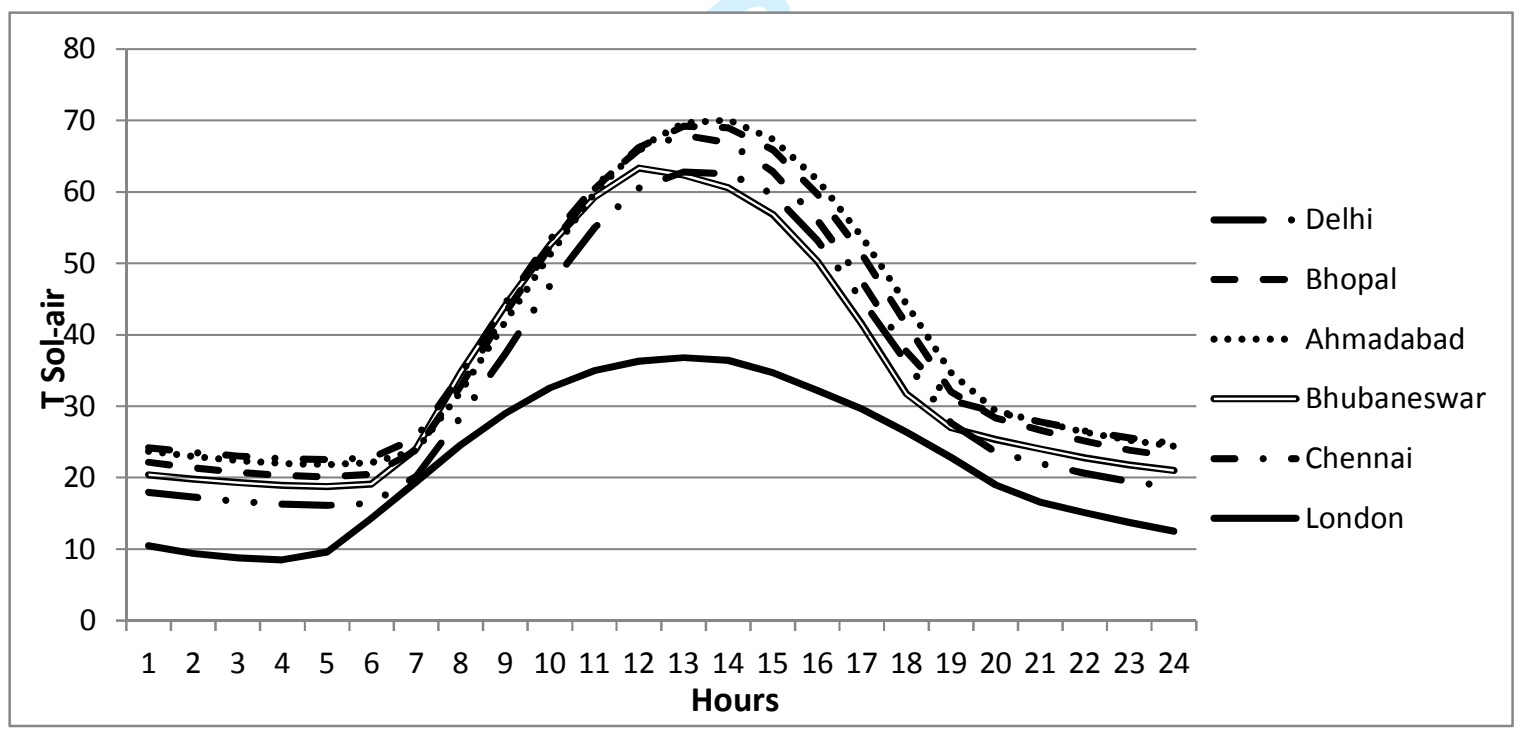

Fig.13. Inter-comparison of flat roof solar-air temperature (Celsius) for Indian locations and London. 


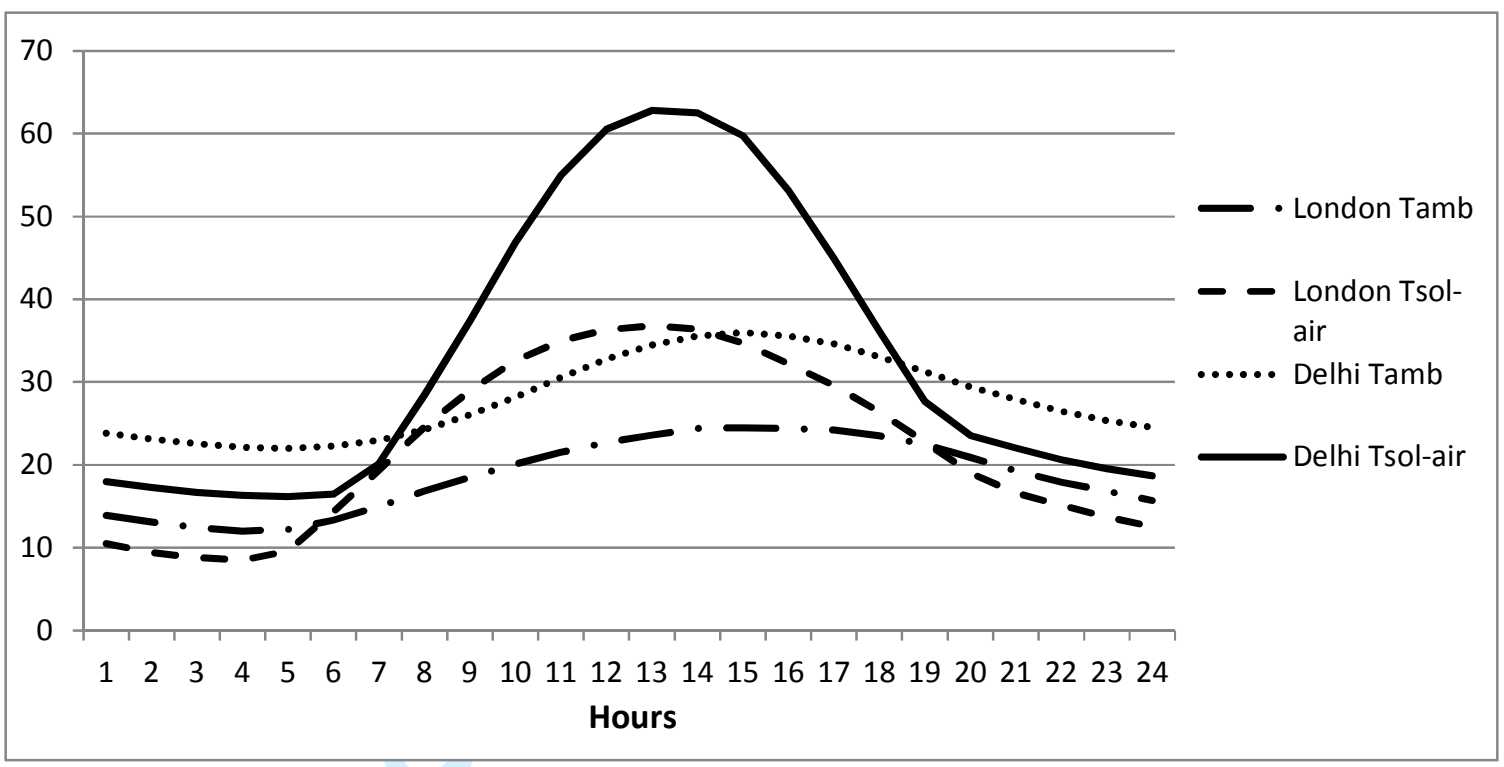

Fig.14. Demonstration of the flat roof sol-air and outdoor ambient temperature differential (Celsius) for Delhi and London.

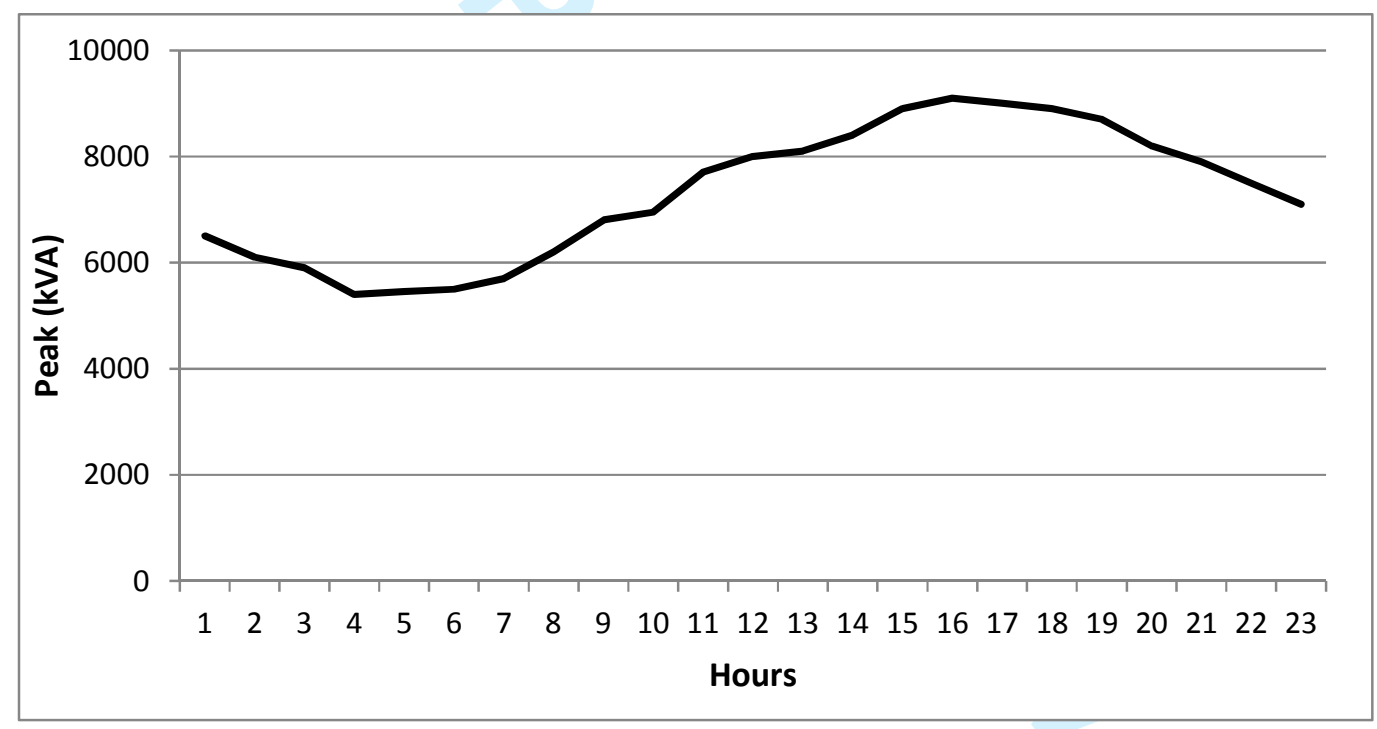

Fig.15. Typical electricity demand profile for the month of July for Delhi grid. 